九州大学学術情報リポジトリ

Kyushu University Institutional Repository

\title{
Dietary Effect of Yeast Extract of Glutathione on Lipid Metabolism and Immune Function of Sprague-Dawley Rats
}

Wu, Po-Sheng

Tokunaga, Yoko

Laboratory of Food Chemistry, Division of Applied Biological Chemistry, Department of Bioscience and Biotechnology, Faculty of Agriculture, Kyushu University

Okura, Ken-ichi

Laboratory of Food Chemistry, Division of Applied Biological Chemistry, Department of Bioscience and Biotechnology, Faculty of Agriculture, Kyushu University

\section{Ikeda, Atsushi}

Laboratory of Food Chemistry, Division of Applied Biological Chemistry, Department of Bioscience and Biotechnology, Faculty of Agriculture, Kyushu University

他

https://doi.org/10.5109/24460

出版情報 : 九州大学大学院農学研究院紀要. 47 (1)，pp.61-66，2002-10-30. Kyushu University バージョン：

権利関係 : 


\title{
Dietary Effect of Yeast Extract or Glutathione on Lipid Metabolism and Immune Function of Sprague-Dawley Rats
}

\author{
Po-Sheng WU, Yoko TOKUNAGA, Ken-ichi OKURA, Atsushi IKEDA, \\ Michiko NONAKA, Hirofumi TACHIBANA and Koji YAMADA
}

\author{
Laboratory of Food Chemistry, Division of Applied Biological Chemistry, \\ Department of Bioscience and Biotechnology, Faculty of Agriculture, \\ Kyushu University, Fukuoka 812-8581, Japan. \\ (Received May 30, 2002 and accepted July 12, 2002)
}

\begin{abstract}
Dietary effect of yeast extract $\mathrm{YH}(\mathrm{YH})$ and glutathione on lipid metabolism and immune function of Sprague-Dawley rats was examined. Dietary effect of these diets was small on growth and tissue weights, as well as the effect on serum levels of cholesterol, triglycerides, phospholipids and tribarbituric acid reactive substances. On the other hand, $\mathrm{LTB}_{4}-$ releasing activity of peritoneal exudate cells was significantly lower in the rats fed $10 \%$ YH diet than the rats fed control or $1 \% \mathrm{YH}$ diet. In the rats fed $0.01 \%$ GSH diet, enough number of peritoneal exudate cells was not recovered. In addition, YH and GSH feeding slightly decreased the levels of serum IgA, IgG and IgM, as well as the productivities of these antibodies in spleen lymphocytes. These results suggest that $\mathrm{YH}$ feeding affects rat immune functions such as eicosanoid and immunoglobulin production.
\end{abstract}

\section{INTRODUCTION}

It has been reported that various food components affect diverse biological functions. Among them, the immunoregulatory effect of food components is related to the incidence or prevention of infectious diseases, allergies, and cancers. For instance, some unsaturated fatty acids regulate allergic reactions such as eicosanoid production through the regulation of lipid metabolism (Terano et al., 1984; Thien et al., 1993). In addition, antioxidants such as $\alpha$-tocopherol (Gu et al., 1994, 1995), tea polyphenols (Matsuo et al., 1996, 1997), and flavonoids (Baumann et al., 1980; Corvazier and Maclouf 1985; Laughton et al., 1991) have been reported to suppress eicosanoid production, probably by inhibiting lipid oxidizing enzymes such as lipoxygenase and cycloxygenase.

In addition, unsaturated fatty acids and antioxidants have been reported to regulate immunoglobulin (Ig) production of rat lymphocytes in vitro in a class-specific manner. For instance, unsaturated fatty acids enhance IgE production of rat and mouse lymphocytes, suppressing the production of IgA, IgG and IgM (Yamada et al., 1996; Hung et al., 1997). Since the enhancement of IgE production by unsaturated fatty acids is cancelled by hydrophobic antioxidants such as $\alpha$-tocopherol, lipid peroxidation in a hydrophobic circumstance seems to be responsible for the enhancement of $\operatorname{IgE}$ production. In addition, tea polyphenols have also been reported to regulate Ig production of rat lymphocytes in a class specific manner (Yamada et al., 1996). These results suggest that lipid metabolism is deeply related to the regulation of Ig production, as well as eicosanoid production.

Glutathione (GSH) is a tripeptide (Glu-Cys-Ala) widely present in micro-organisms, 
as well as in animals and plants. It exerts diverse physiological functions such as detoxification in the liver, production and metabolism of various biomaterials, suppression of peroxidation and radiation disorders, protection of reactive thiol group. In the present study, we examined the dietary effect of GSH and GSH-rich yeast extract on lipid metabolism and immune function of Sprague-Dawley rats.

\section{MATERIALS AND METHODS}

\section{Animals and diets}

Yeast extract $\mathrm{YH}(\mathrm{YH})$ is a GSH-rich yeast extract afforded by Kohjin (Tokyo, Japan). Four-week-old male Sprague-Dawley rats were obtained from Seac Yoshitomi (Yoshitomi, Japan) and individually housed in the room of Biotron Institute, Kyushu University, with a controlled temperature of $20-23^{\circ} \mathrm{C}$ and light from 08:00 to 20:00. After acclimatizing for 7 days, the rats were divided into 4 groups with 5 animals each, and free access was provided to the experimental diets and to deionized water. The diets were prepared according to the recommendations of the American Institute of Nutrition AIN-93G, and contained $36.75 \%$ cornstarch, $20 \%$ casein, $13.2 \% \quad \alpha$-cornstarch, $10 \%$ sucrose, $10 \%$ safflower oil, $5 \%$ cellulose, $3.5 \%$ mineral mixture, $1 \%$ vitamin mixture, $0.3 \%$ L-cystine, $0.25 \%$ choline bitartrate and $0.0014 \%$ tert-butylhydroquinone. YH were added to the diet at the 1 or $10 \%$ level in place of cornstarch, and GSH at the $0.01 \%$ level which is corresponding to the level in $1 \% \mathrm{YH}$ diet.

After three weeks of feeding, the rats were killed by withdrawing blood from the abdominal aorta under diethyl ether anesthesia. The heart, lung, liver, kidney, brain, spleen and epididymal adipose tissue of each rat were immediately excised and weighed. Lymphocytes were isolated from the spleen and mesenteric lymph node (MLN) to measure their Ig productivity. The levels of serum cholesterol, triglycerides and phospholipids were enzymatically determined with commercial kits, such as Cholesterol Test, TG-G Test and PL-B Test (Wako Pure Chemicals, Osaka, Japan). A thiobarbituric acid test kit was purchased from Wako and the amount of thiobarbituric acid-reactive substance (TBARS) was measured according to the directions of supplier. This experiment was carried out under the guidelines for Animal Experiments in the Faculty of Agriculture and Graduate Course of Kyushu University, and according Law No. 105 and Notification No. 6 of the Japanese government.

\section{Cells and cell culture}

Spleen and MLN lymphocytes were isolated from the rats that had been fed the above diets for 3 weeks, using Lympholyte-rat (Cedarlene, Hornby Canada), and cultured for 24 $\mathrm{hr}$ in the RPMI 1640 medium (Nissui Pharmaceutical, Tokyo, Japan) supplemented with $10 \%$ fetal bovine serum (FBS; Intergen, Purchase, NY) as described previously (Lim et al., 1994). The IgA, IgG and IgM contents in the serum and culture supernatant were determined by the enzyme-linked immunosorbent assay (ELISA) as described previously (Lim et al., 1994).

\section{Statistics}

Data were analyzed by Duncan's new multiple-range test (Duncan, 1955) to deter- 
mine the exact nature of the differences among groups.

\section{RESULTS AND DISCUSSION}

\section{Effect on growth and tissue weight}

Table 1 shows the effect of YH and GSH feeding on food intake and weight gain. Weight gain of the rats fed $1 \% \mathrm{YH}$ diet was higher than that of the rats fed control diet, and food intake of the former was lower than that of the latter. However, there was no significant difference in these indices and food efficiency.

Table 1. Effect of yeast extract or glutathione feeding on the growth of Sprague-Dawley rats.

\begin{tabular}{lcccc}
\hline & $\begin{array}{c}\text { Initial body weight } \\
(\mathrm{g})\end{array}$ & $\begin{array}{c}\text { Weight gain } \\
(\mathrm{g})\end{array}$ & $\begin{array}{c}\text { Food intake } \\
\text { (g/day) }\end{array}$ & $\begin{array}{c}\text { Food efficiency } \\
\text { (Weight gain/food intake) }\end{array}$ \\
\hline Control & $144 \pm 5$ & $123 \pm 10$ & $19.0 \pm 0.5$ & $0.31 \pm 0.02$ \\
$1 \%$ YH & $144 \pm 2$ & $132 \pm 3$ & $18.4 \pm 0.2$ & $0.34 \pm 0.01$ \\
$10 \%$ YH & $144 \pm 5$ & $126 \pm 5$ & $18.9 \pm 0.5$ & $0.32 \pm 0.01$ \\
$0.1 \%$ GSH & $144 \pm 5$ & $128 \pm 7$ & $18.5 \pm 0.3$ & $0.33 \pm 0.02$ \\
\hline
\end{tabular}

Data are means $\pm S E(n=5)$.

On the other hand, significant changes of tissue weight were observed in some tissues (Table 2). Heart weight of the $1 \%$ YH group was significantly lower than that of the control rats, and $10 \% \mathrm{YH}$ and $0.1 \% \mathrm{GSH}$ groups gave intermediate values. In the case of kidney, 10\% YH group gave a significantly higher value than control group, and the other groups gave intermediate values. Adipose tissue weights of $1 \% \mathrm{YH}, 10 \% \mathrm{YH}$ and $0.1 \%$ GSH groups were significantly higher than that of control rats. There was no significant effect in lung, liver, brain and spleen weights. These results suggest that the effect of $\mathrm{YH}$ or GSH intake was small on growth and tissue weight of Sprague-Dawley rats, except epididymal adipose tissue weight. The increase of adipose tissue weight of the $0.1 \%$ GSH group was smaller than those $1 \%$ and $10 \% \mathrm{YH}$ groups, though there was no significant difference among them.

Table 2. Effect of yeast extract or glutathione feeding on the tissue weights of Sprague-Dawley rats.

\begin{tabular}{lccccccc}
\hline \multicolumn{7}{c}{ Tissue weight $(\mathrm{g} / 100 \mathrm{~g}$ body weight) } \\
\cline { 2 - 7 } & Heart & Lung & Liver & Kidney & Brain & Spleen & Adipose \\
\hline Control & $0.37 \pm 0.01^{\mathrm{a}}$ & $0.47 \pm 0.01$ & $4.10 \pm 0.19$ & $0.81 \pm 0.03^{\text {ab }}$ & $0.70 \pm 0.01$ & $0.22 \pm 0.01$ & $1.22 \pm 0.05^{\mathrm{a}}$ \\
$1 \% \mathrm{YH}$ & $0.32 \pm 0.01^{\mathrm{b}}$ & $0.46 \pm 0.01$ & $4.18 \pm 0.12$ & $0.81 \pm 0.02^{\mathrm{ab}}$ & $0.67 \pm 0.01$ & $0.20 \pm 0.01$ & $1.86 \pm 0.04^{\mathrm{b}}$ \\
$10 \% \mathrm{YH}$ & $0.33 \pm 0.01^{\mathrm{ab}}$ & $0.47 \pm 0.02$ & $4.37 \pm 0.14$ & $0.86 \pm 0.01^{\mathrm{a}}$ & $0.70 \pm 0.03$ & $0.22 \pm 0.01$ & $1.88 \pm 0.02^{\mathrm{b}}$ \\
$0.1 \% \mathrm{GSH}$ & $0.35 \pm 0.02^{\mathrm{ab}}$ & $0.51 \pm 0.05$ & $3.91 \pm 0.16$ & $0.78 \pm 0.02^{\mathrm{b}}$ & $0.65 \pm 0.02$ & $0.22 \pm 0.01$ & $1.77 \pm 0.01^{\mathrm{b}}$ \\
\hline
\end{tabular}

Data are means $\pm \mathrm{SE}(\mathrm{n}=5)$ and values without a common superscript letters are significantly different at $p<0.05$. 


\section{Effect on serum lipid levels}

Table 3 shows the effect of YH and GSH feeding on serum lipid levels. Cholesterol levels of $\mathrm{YH}$ and GSH groups were lower that that of control group, but there was no significant difference among them. Triglyceride level of the $10 \% \mathrm{YH}$ group was higher than that of control group and the level of $0.1 \%$ GSH group was lower than that of control rats. However, there was no significant difference among them. In addition, there was no significant difference in serum phospholipid level, as well as the level of TBARS, an index of lipid peroxidation. These results suggest that the effect of YH and GSH feeding was not so significant.

Table 3. Effect of yeast extract or glutathione feeding on serum lipid and TBARS levels of Sprague-Dawley rats

\begin{tabular}{lcccc}
\hline & $\begin{array}{c}\text { Cholesterol } \\
(\mathrm{mg} / \mathrm{dl})\end{array}$ & $\begin{array}{c}\text { Triglyceride } \\
(\mathrm{mg} / \mathrm{dl})\end{array}$ & $\begin{array}{c}\text { Phospholipids } \\
(\mathrm{mg} / \mathrm{dl})\end{array}$ & $\begin{array}{c}\text { TBARS } \\
(\mathrm{ng} / \mathrm{dl})\end{array}$ \\
\hline Control & $65 \pm 7$ & $53 \pm 13$ & $148 \pm 11$ & $0.15 \pm 0.02$ \\
$1 \% \mathrm{YH}$ & $62 \pm 3$ & $57 \pm 12$ & $154 \pm 6$ & $0.20 \pm 0.00$ \\
$10 \% \mathrm{YH}$ & $59 \pm 4$ & $63 \pm 16$ & $156 \pm 9$ & $0.17 \pm 0.02$ \\
$0.1 \%$ GSH & $56 \pm 8$ & $38 \pm 7$ & $141 \pm 15$ & $0.18 \pm 0.01$ \\
\hline
\end{tabular}

Data are means $\pm \mathrm{SE}(n=5)$.

\section{Effect on immune functions}

Table 4 shows the effect of $\mathrm{YH}$ or GSH feeding on immune indices. $\mathrm{LTB}_{4}$ releasing activity of PEC isolated from the 10\% YH group was significantly lower that those obtained from the rats of control and 1\% YH groups. In 0.1\% GSH group, enough number of PEC was not isolated. Such decrease of $\mathrm{LTB}_{4}$ releasing activity has been reported in the rats fed n-3 unsaturated fatty acids (Sugano et al., 1998; Hung et al., 1999, 2000) or antioxidants (Gu et al., 1995; Matsuo et al., 2000). These fatty acids suppress the productivity of 4-series leukotrienes through the decrease of the level of arachidonic acids in membrane phospholipids. On the other hand, antioxidants such as tea polyphenols suppress the activity irrespective of arachidonic acid level, probably by inhibiting the activity of lipoxygenase (Matsuo et al, 2000). Since the inhibitory activity was observed only in lipophilic antioxidants, permeation through cell membrane seems to be essential. Though the effect of GSH feeding was not clarified because of the lack of PEC in this experiment, hydrophilic GSH may not be effective to the suppression of $\mathrm{LTB}_{4}$ production. Thus, it is possible that the other suppressive factors in YH is responsible for the reduction of $\mathrm{LTB}_{4}$ releasing activity.

In the case of serum Ig levels, $10 \%$ YH group gave a significantly lower IgA level than other groups. On the other hand, 1\% YH group gave a significantly lower IgG level than other groups. Serum IgM levels of YH and GSH groups were significantly lower than that of control rats. When spleen or MLN lymphocytes isolated from the rats fed these diets were cultured in the medium without dietary components, some significant differences were observed. In spleen, $10 \% \mathrm{YH}$ and $0.1 \%$ GSH groups exerted IgA productivities sig- 
Table 4. Effect of yeast extract or glutathione feeding on immune indices of Sprague-Dawley rats.

\begin{tabular}{|c|c|c|c|c|}
\hline & Control & $1 \% \mathrm{YH}$ & $10 \% \mathrm{YH}$ & $0.1 \% \mathrm{GSH}$ \\
\hline \multicolumn{5}{|l|}{$\mathrm{LTB}_{4}$ releasing activity } \\
\hline PEC (ng/ $10^{6}$ cells) & $19.4 \pm 1.7^{\mathrm{a}}$ & $19.3 \pm 1.0^{\mathrm{a}}$ & $14.1 \pm 0.2^{\mathrm{b}}$ & Not tested \\
\hline \multicolumn{5}{|l|}{ Serum Ig level } \\
\hline $\operatorname{Ig} \mathrm{A}(\mu \mathrm{g} / \mathrm{ml})$ & $28.7 \pm 0.5^{\mathrm{a}}$ & $28.2 \pm 0.3^{\mathrm{a}}$ & $25.0 \pm 0.5^{b}$ & $27.5 \pm 0.8^{\mathrm{a}}$ \\
\hline $\operatorname{IgG}(\mathrm{mg} / \mathrm{ml})$ & $1.2 \pm 0.1^{\mathrm{a}}$ & $0.6 \pm 0.1^{b}$ & $1.4 \pm 0.2^{\mathrm{a}}$ & $1.0 \pm 0.2^{\mathrm{ab}}$ \\
\hline $\operatorname{IgM}(\mu \mathrm{g} / \mathrm{ml})$ & $263 \pm 20^{\mathrm{a}}$ & $217 \pm 12^{\mathrm{b}}$ & $193 \pm 10^{b}$ & $222 \pm 8^{b}$ \\
\hline \multicolumn{5}{|c|}{$\begin{array}{l}\text { Ig productivity of spleen } \\
\text { lymphocytes }\end{array}$} \\
\hline $\operatorname{IgA}(\mathrm{ng} / \mathrm{ml})$ & $20.5 \pm 0.5^{\mathrm{a}}$ & $18.5 \pm 1.0^{\mathrm{ab}}$ & $16.1 \pm 1.3^{\mathrm{b}}$ & $16.2 \pm 1.2^{\mathrm{b}}$ \\
\hline IgG (ng/ml) & $48.6 \pm 2.6^{\mathrm{a}}$ & $44.3 \pm 3.0^{\mathrm{ab}}$ & $41.8 \pm 2.8^{\mathrm{ab}}$ & $37.9 \pm 2.6^{\mathrm{b}}$ \\
\hline $\operatorname{IgM}(\mathrm{ng} / \mathrm{ml})$ & $51.1 \pm 2.2^{\mathrm{a}}$ & $44.4 \pm 2.9^{\text {ab }}$ & $40.2 \pm 4.6^{\mathrm{b}}$ & $45.8 \pm 1.0^{\mathrm{ab}}$ \\
\hline \multicolumn{5}{|l|}{ Ig productivity of MLN } \\
\hline IgA (ng/ml) & $19.0 \pm 1.1$ & $20.7 \pm 1.0$ & $20.3 \pm 0.7$ & $19.5 \pm 0.5$ \\
\hline $\operatorname{IgG}(\mathrm{ng} / \mathrm{ml})$ & $40.2 \pm 3.0^{\mathrm{ab}}$ & $45.3 \pm 1.1^{\mathrm{a}}$ & $44.0 \pm 2.2^{\mathrm{a}}$ & $37.4 \pm 1.3^{b}$ \\
\hline $\operatorname{IgM}(\mathrm{ng} / \mathrm{ml})$ & $2.5 \pm 1.2^{\mathrm{a}}$ & $3.4 \pm 1.1^{\mathrm{b}}$ & $2.6 \pm 0.8^{\mathrm{a}}$ & $0.7 \pm 0.3^{a}$ \\
\hline
\end{tabular}

Data are means $\pm S E(n=5)$ and values without a common superscript letters are significantly different at $p<0.05$.

nificantly lower than control rats, $1 \% \mathrm{YH}$ group gave an intermediate value. IgG productivity of the $0.1 \%$ GSH group was significantly lower than that of control rats, and $\mathrm{YH}$ groups gave intermediate values. On the other hand, IgM productivity of the $10 \% \mathrm{YH}$ group was significantly lower than that of control rats, and $1 \%$ YH and $0.1 \%$ GSH groups gave intermediate values. In the case of MLN lymphocytes, there was no significant difference in IgA productivity. IgG productivity of the $0.1 \%$ GSH group was significantly lower than those of $\mathrm{YH}$ groups and control rats gave an intermediate value. In the case of IgM productivity, 1\% $\mathrm{YH}$ group gave a value significantly higher than control rats and $0.1 \%$ GSH group gave a value significantly lower than control rats. These results suggest that $\mathrm{YH}$ and GSH feeding affect to Ig productivity of rat lymphocytes with different manners.

Similar modulation of Ig productivity has been reported in the rat fed water-soluble dietary fibers (Lim et al., 1997; Yamada et al., 1999). In this case, significant increase of serum IgA level was induced in the rats fed pectin, glucomannan or galactomannan, as well as the significant enhancement of IgA and IgG productivity in MLN lymphocytes. Such increase of IgA and IgG levels may be useful for the activation of self defensive system. On the contrary, $\mathrm{YH}$ or GSH feeding exerted a tendency to inhibit the production of these antibodies, though the effect was much weaker than the effect of dietary fibers. To estimate physiological meaning of the Ig production-regulating activity of YH and GSH more correctly, further experiment should be necessary. 


\section{REFERENCES}

Baumann, J., F. Bruchhausen, and G. Wurm. 1980 Flavonoids and related compounds as inhibitors of arachidonic acid peroxidation. Prostaglandins, 20: 627-639

Corvazier, E., and J. Maclouf 1985 Interference of some flavonoids and non-steroidal anti-inflammatory drugs with oxidative metabolism of arachidonic acid by human platelet and neutrophils. Biochim. Biophys. Acta, $\mathbf{8 3 5}$ : $315-321$

Duncan D. B. 1955 Multiple range and multiple F test. Biometrics, 11: 1-42

Gu, J-Y., M. Nonaka, K. Yamada, K. Yoshimura, M. Takasugi, Y. Ito, and M. Sugano 1994 Effects of sesamin and $\alpha$-tocopherol on the production of chemical mediators and immunoglobulins in Brown-Norway rats. Biosci. Biotechnol. Biochem., 58: 1855-1858

Gu, J-Y., Y. Wakizono, A. Tsujita, B. O. Lim, M. Nonaka, K. Yamada, and M. Sugano 1995 Effects of sesamin and $\alpha$-tocopherol, individually or in combination, on the polyunsaturated fatty acid metabolism, of chemical mediator production and immunoglobulin levels in Sprague-Dawley rats. Biosci. Biotechnol. Biochem., 59:2198-2202

Hung, P., K. Yamada, B. O. Lim, M. Mori, T. Yuki, and M. Sugano 1997 Effect of unsaturated fatty acids and $\alpha$-tocopherol on immunoglobulin levels in culture medium of rat mesenteric lymph node and spleen lymphocytes. J. Biochem., 121: 1054-1060

Hung, P., S. Kaku, S. Yunoki, K. Ohkura, J-Y. Gu, I. Ikeda, M. Sugano, K. Yazawa, and K. Yamada 1999 Dietary effect of EPA-rich and DHA-rich fish oils on the immune function of Sprague-Dawley rats. Biosci. Biotechnol. Biochem., 63: 135-140

Hung, P., J-Y. Gu, S. Kaku, S. Yunoki, K. Ohkura, I. Ikeda, H. Tachibana, M. Sugano, K. Yazawa, and K. Yamada 2000 Dietary effect of eicopentaenoic and docosahexaenoic acid esters on lipid metabolism and immune parameters in Sprague-Dawley rats. Biosci. Biotechnol. Biochem., 64: 2588-2593

Laughton, M. J., P. J. Evans, M. A. Moroney, J. R. S. Hoult, and B. Halliwell 1991 Inhibition of mammalian 5-lipoxygenase and cyclooxygenase by flavonoids and phenolic dietary additives. Biochem. Phammacol., 42, 1673-1681

Lim, B. O., K. Yamada, and M. Sugano 1994 Effect of bile acids and lectins on immunoglobulin production in rat mesenteric lymph node lymphocytes. In Vitro Cell. Develop. Biol., 30: 407-413

Lim, B. O., K. Yamada, M. Nonaka, Y. Kuramoto, P. Hung, and M. Sugano 1997 Dietary fibers modulate indices of intestinal immune functions in rats. J. Nutr., 127: 663-667

Matsuo, N., K. Yamada, K. Yamashita, K. Shoji, M. Mori, and M. Sugano 1996 Inhibitory effect of tea polyphenols on histamine and leukotriene $\mathrm{B}_{4}$ release from rat peritoneal exudate cells. In Vitro Cell. Develop. Biol., 32: 340-344

Matsuo, N., K. Yamada, K. Shoji, M. Mori, and M. Sugano 1997 Effect of tea polyphenols on histamine release from rat basophilic leukemia (RBL-2H3) cells: The structure-inhibitory activity relationship. Allergy, 52: 58-64

Matsuo, N., K. Yamada, M. Mori, K. Shoji, T. Ueyama, S. Yunoki, K. Yamashita, M. Ozeki, and M. Sugano 2000 Inhibition by dietary tea polyphenols of chemical mediator release from rat peritoneal exudate cells. Biosci. Biotechnol. Biochem., 64: 1437-1443

Sugano, M., A. Tsujita, M. Yamasaki, M. Noguchi, and K. Yamada 1998 Conjugated linoleic acid modulates tissue levels of chemical mediators and immunoglobulins in rats. Lipids, 33: 521-527

Terano, T., J. A. Salmon, and S. Moncada 1984 Effect of orally administered eicosapentaenoic acids (EPA) on the formation of leukotriene $B_{4}$ and leukotriene $B_{5}$ by rat leukocytes. Biochem. Pharmacol., 33: $3071-3076$

Thien, F. C. K., M. P. Hallsworth, C. Soh, and T. H. Lee 1993 Effect of exogenous eicosapentaenoic acid on generation of leukotriene $\mathrm{C}_{4}$ and leukotriene $\mathrm{C}_{5}$ by calcium ionophore-activated human eosinophils in vitro. J. Immunol., 150: 3546-3552.

Yamada, K., P. Hung, K. Yoshimura, S. Taniguchi, B. O. Lim, and M. Sugano 1996 Effect of unsaturated fatty acids and antioxidants on immunoglobulin production by mesenteric lymph node lymphocytes of Sprague-Dawley rats. J. Biochem., 120: 138-144

Yamada, K., Y. Tokunaga, A. Ikeda, K. Ohkura, S. Mamiya, S. Kaku, M. Sugano, and H. Tachibana 1999 Dietary effect of guar gum and its partially hydrolyzed product on lipid metabolism and immune function of Sprague-Dawley rats. Biosci. Biotechnol. Biochem., 63: 2163-2167 